\title{
Apresentação: dossiê olhares sobre a Antiguidade e Idade Média: objetos distantes, questões presentes
}

Para que serve a história? Pergunta de um filho ao pai historiador, Marc Bloch, que motivou a escrita de um livro - o último escrito do referido autor e obra recorrente nas disciplinas introdutórias dos cursos de história. Em Apologia da História ou O Ofício de Historiador $^{l}$ Bloch desenvolve reflexões que possibilitam mais de uma resposta a questão posta pelo filho, mas também se debruça sobre o trabalho historiográfico, o qual nomeia, de forma pertinente, como ofício.

Entendida como ofício, a história demanda o exercício constante de suas diversas atividades para o aperfeiçoamento das habilidades, seja de formular perguntas, ou de buscar e apresentar possíveis respostas. A proposta deste dossiê é justamente apresentar trabalhos de aprendizes do ofício de historiador que se encontram em diferentes estágios de formação acadêmica, desde estudantes de graduação até doutorandos. Provenientes de diversas regiões e portadores de experiências próprias, os autores nos agraciam com diferentes olhares sobre a antiguidade e a idade média, demonstrando que o estudo de tais temporalidades atrai os esforços de pesquisadores com questões e objetivos não necessariamente próximos.

${ }^{1}$ BLOCH, Marc. Apologia da história, ou, O ofício de historiador. André Telles (Trad.). Rio de Janeiro: Jorge Zahar Ed., 2001.

Revista Vernáculo n. ${ }^{\circ} 43$ - primeiro semestre/2019

ISSN 2317-4021 
Se Bloch teve dificuldades para responder ao filho sobre a serventia da história, o que dizer da utilidade do estudo de tempos tão recuados em um período no qual o futuro parece se aproximar com uma velocidade cada vez maior? Lendo os artigos que seguem, o leitor poderá comprovar a indicação de Marc Bloch que a história nos entretém. ${ }^{2}$ Mas, como o autor desenvolve, há muito mais que isso. Nosso tempo nos põe várias questões, para as quais buscamos respostas por variados caminhos - na tecnologia, na fé, na organização de grupos e, entre outras possibilidades, no passado. Não que o estudo da organização política medieval vá nos proporcionar o entendimento do que ocorre hoje, mas aumenta nosso repertório mental e possibilita a proposta de apontamentos diferentes em torno de problemas atuais, pensando isso como exercício do grupo humano e não necessariamente enquanto tarefa individual de cada historiador.

As produções que compõem este número da revista Vernáculo nos trazem questionamentos sobre guerra, economia, natureza, criação de mitos e outros assuntos (problemas atuais, mas não inéditos na experiência da nossa espécie). Foram produzidos por autores de sete instituições diferentes, localizadas em quatro estados brasileiros (Goiás, Mato Grosso, Paraná e Sergipe) e em Portugal, possibilitando leituras a partir de perspectivas diversificadas.

O artigo de abertura do dossiê é de autoria de Douglas de Freitas Almeida Martins, intitulado $O$ dever da caridade aos pobres:

${ }^{2}$ Idem.p. 42.

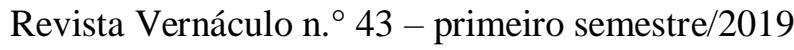

ISSN $2317-4021$ 
circulação de excedente, furto e a construção da noção de propriedade no interior da Ordem dos Frades Menores a partir das Legenda Maior e da Vita Secunda, trata dos modelos franciscanos de interação com a vida material presentes nas obras referidas, apresentando relações entre a economia e a espiritualidade.

O texto seguinte, Dos montes à vila: considerações em torno da vila medieval portuguesa de aldeia galega da merceanato ponímia, povoamento, administração, nossa contribuição portuguesa, escrito por Inês Sofia Lourenço Olaia, centra a análise na evolução do nome da região hoje conhecida como Aldeia Galega, entre os séculos XIII e XIV. A autora busca ainda as diferenças entre a nomenclatura em documentação local e proveniente da chancelaria régia.

Lorena da Silva Vargas, em Luzes e sombras: a natureza na peregrinação a Santiago de Compostela segundo o Codex Calixtinus (século XII), analisa a influência da natureza sobre os peregrinos a caminho de Santiago de Compostela, tendo como fonte principal o Livro do peregrino.

A pergunta colocada por Willian Perpétuo Busch em $A$ construção da Cavalaria de Rei Arthur em Thomas Malory a partir do juramento do Pentecostes objetiva chegar ao entendimento de como a ideia de cavalaria presente no juramento de Pentecostes foi forjada, atentando para o contexto de produção do texto e da vida do autor, bem como para o desenvolvimento do ideal de cavalaria, o qual teria Arthur como um dos modelos.

Revista Vernáculo n. ${ }^{\circ} 43$ - primeiro semestre/2019

ISSN $2317-4021$ 
Também relacionado à cavalaria temos As habilidades militares de Ricardo I no Itinerarium Peregrinorum et Gesta Regis Ricardi (1217-1222), de Gabriel Toneli Rodrigues. O artigo pretende apresentar as habilidades de rei cavaleiro atribuídas pela crônica em questão a Ricardo I e entender como esta construção pode ser lida como uma crítica a João I e tentativa de promoção de Henrique III, reis que sucederam Ricardo no trono inglês.

Ives Leocelso Silva Costa analisa as escolhas feitas por França e Inglaterra no princípio do confronto que opôs os dois reinos por mais de um século. Cavalaria e prática militar na fase inicial da guerra dos cem anos (1346-1356) extrapola os aspectos militares para compreender as razões que levaram à insistência dos franceses na utilização da cavalaria, apesar de derrotas para tropas inglesas desmontadas.

Em Invasão ou "guerra pela paz"? O retorno da rainha Isabella à Inglaterra (1325-1327), Janaina Bruning Azevedo objetiva compreender o que o movimento realizado pela rainha Isabella representou para a Inglaterra então governada por seu esposo, Eduardo II. Artigo com objeto mais recuado temporalmente, Romanos e nãoromanos: o nascimento da christianitas de Gabriel Irinei Covalchuk discute o desenvolvimento da ideia de romanidade tendo como parâmetro a relação com o cristianismo.

Fechando o dossiê, temos um artigo de autoria coletiva: $A$ leitura da lenda da dama do pé de cabra na perspectiva das novas mídias digitais, resultado de uma oficina realizada na Universidade 
Federal do Paraná, que visa discutir as possibilidades oferecidas pelas novas tecnologias para a divulgação do conhecimento, partindo da análise da lenda da Dama do Pé de Cabra, história registrada no período medieval em Portugal. Esperamos que os textos aqui reunidos possibilitem reflexões e engendrem diálogos que colaborem com a continuidade do exercício historiográfico. Desejamos a todos uma boa leitura!

Willian Funke Mateus Alves Nedbajluk 